\title{
Film for Preserving Indigenous Knowledge Minangkabau Culture
}

\author{
M. Fadli ${ }^{1}$, D Hasfera ${ }^{2}$, Arwendria ${ }^{3}$ \\ \{1mfadli@uinib.ac.id, 2dianhasfera@uinib.ac.id, ${ }^{3}$ arwendriadahlan@uinib.ac.id $\}$ \\ ${ }^{1,2,3}$ Universitas Islam Negeri Imam Bonjol Padang, Indonesia
}

\begin{abstract}
This article aims to describe and analyze about the effectiveness of film as a media of transfer of indigenous knowledge in Minangkabau. A research background it had started organizational memory loss in globalization era. The film was one of the media effective in the transfer of local knowledge to the youth generation, because it is packed with stylish and attractive, thus the younger generation interested to learn the local knowledge. There are a few films that analyzed Tenggelam Kapal Van Der Wijk, Sengsara Membawa Nikmat, Surau dan Silek, dan Siti Nurbaya, its contains the knowledge of the Minangkabau indigenous knowledge. This research using survey method at 30 people of the young generation in Minangkabau by asking seven questions that include the benefits that accrue to the second post in the learning process of local knowledge of the policy. The study concluded that use of film in preservation of indigenous knowledge there are several advantages: (a) the learning process so interesting, (b) stimulated of the imagination, (c) critical understanding of historical events and culture, (d) make it easier to explain the events, conditions and customs rules, (e) make the abstract becomes concrete, (f) quick recall and understand the terms of customs and culture, (g) the film as a delightful audio visual media, (h) making learning effective and active, and (i) improve learning results. Thus the movie can serve as an effective medium in the preservation of indigenous knowledge
\end{abstract}

Keywords: Film, Indigenous Knowledge, Minangkabau Culture

\section{INTRODUCTION}

Dat de adat met de gslachten wisselt en fitelijk geen ogenblik stil staat" [1] .The sentence written by Snouck Hurgronje in the book De Atjehers at 1983, explains the change continued from generation to generation. Similarly with transfer of indigenous knowledge that keeps changing from generation to generation. The change is visible from various aspects such as storage media, and channels in the transfer of indigenous knowledge.

Indigenous knowledge is not common knowledge as other knowledge. Indigenous knowledge is unique, and only found in a specific community with cultural and territorial base[2]. Prisident of The World Bank James D. Wolfensohn[3], explain the following indigenous knowledge 'indigenous knowledge is an integral part of the culture ad history of a local community. Based on the explanation means indigenous knowledge is the accumulation of experiences, or the already agreed norms in a society.

The development of information technology have a positive and negative impact. In defending the existence of local knowledge, information and communication technology is often 
regarded as an internal threat that makes the knowledge became extinct and left by indigenous peoples.

A growing opinion in the community is not wrong, because information technology has cut time and space, and gives the potential occurrence of acculturation because information technology has cut time and space, and gives the potential occurrence of acculturation. This is worrying about taking action against the existence of local knowledge passed down from previous generations, when information and communication technologies provide great oppopportunities in the preservation of Indigenous knowledge.

The limitations of the knowledge of the young generation of the policy at the moment about Minangkabau Indigenous Knowledge caused by the limited Indigenous knowledge can be learned explicitly. Prof. Dr. L. Jan Slikkerveer convey as the following "If we take a look at local community, many pieces of knowledge that we can't find in books are widely available"[4]. Meanwhile, Faust [5] also explains "80\% of the most important knowledge is unconscious and only $20 \%$ can be found in memos or books".

The process of succession of such local knowledge it seems that it is not as easy as bequeath the objects intangible cultural is understood explicitly. The symbols presented in the communication process orally is not necessarily directly can be fully acceptable to the people who receive such information because it requires interpretation and frame of reference to the same matter.

Therefore, local knowledge in the form of tacit knowledge i.e. knowledge still stored in the memory of the owner's knowledge of course need a strategy and communication systems in order to process such communications can run effectively. It will have an impact on kebertanan a local knowledge in the community sector in the local area.

One of the ways that can be done in preserving local knowledge is to disseminate the knowledge in the community owner's knowledge as well as other community through exchange of indigenous knowledge. Such activity is a way that can help improve the understanding of the community in the group against existing local knowledge Exchange of indigenous knowledge can be done through six stages,recognition and identification, validation, recording and documentation, storage, transfer and dissemination [6]

To keep the existence of local knowledge the pattern of Transfer of Knowledge is a form of process of communicating knowledge. Local knowledge are intagible communicated likely to use verbal communication patterns Indigenous Knowledge For Development a Framework For Action[6] .Describes the activities of the transfer of knowledge as follows "The transfer of IK goes beyond conveying it to the potential recipients. An important element of the transfer is to test the knowledge in the new environment. Economic and technical feasibility, social and environmental impact and other criteria as deemed necessary by the recipients need to be examined [6]

Transfer of knowledge is the activity of communication that occurs through interaction. It is explained by the Everrett M.Rogers[7] as the following "communication is a process by which an idea is transferred from the source to one or more recipients with a view to changing their behaviour". Thus it can be understood that the process of knowledge transfer is the transfer of symbols, the symbols had taken can be understood by others in hopes to change the attitude of the person's knowledge, enrich againts the message in the process of communication.

A few decades later cineas in Indonesia has begun designing the films with the theme local knowledge Minangkabau culture and setting. Some of these films include Tengelam Kapal Van Der Wijk, Merantau, Siti Nurbaya, Sengsara Membawa Nikmat, Surau dan Silek as well as many other movies. Row of the fim got the attention and considerable acclaim from the public 
Among the audience members tend to come from young people age 17 - 30 years enjoy learnig through watch the movies.

This suggests that the movie the art of visual storytelling can be one of the media in the transfer of local knowledge to the younger generation as a medium of instruction. So that local knowledge can be preserved through the transfer of knowledge to the next generation.

\section{RESEARCH METHODS}

This article uses survey methods, refer to the explanation Sherri L. Jackson[8] where respondents and interviewees will be questioned on their knowledge about Film as a medium of learning and the preservation of local wisdom Minangkabau. Further describe their opinions in accordance with the research instrument used, in this case there are 7 questions which are filled in by the respondent

In accordance with the instrument of research, research data obtained via the question form or questionnaire that is collecting information from 30 respondent via kusioner, subsequently conducting interviews with experts. The interview in question here is the category of semi structured interviews[9].

To clarify the concepts and theories that are discussed also conducted the study of literature. A systematic literature review, according to Barbara Kitchenham[10] it is the means to identify, evaluate and interpret existing research sources relevant to the research question, topic areas, or phenomenon of interest in this case is concerned with the use of film as a means of preservation of local wisdom Minangkabau. Data collection techniques [11]the study of literature penelaahannya committed against books, litertur-literature, notes, and reports that there are dependencies with the discussion, namely the film as a means of preserving local wisdom The Minangkabau.

\section{RESULT AND DISCUSSION}

\subsection{The Role Of Film As A Means Of Learning}

The film is one medium that also contributes to the development of education. This is because the movie is very great mass media of his ability to help the teaching-learning process in a wide scale. The role of film in the world of education [12] among others as follows.

It is a common learning denominator, both children are smart or slow will gain something from the same film. Reading skills or a mastery of language that less will be resolved with the use of film.

1. Movie can display back past and present the return of historical events of the past

2. Film can wander with frisky from one country to another, the horizon became very wide, the outside world can be brought in the classroom.

3. Film can present a theory or practice from the impersonal to the special or vice versa.

4. Movie can bring in an expert and showcased in its class.

5. Movie can use techniques such as color, slow-motion, animation, and so on to display particular details.

6. The Film attracted the attention of children

7. The movie more realistic, can be repeated, terminated, and so on according to your needs. Abstract things become clear

8. Film can overcome the limitation of power of our senses, especially vision

9. Film can stimulate or motivate children's activities 
In addition to its role in the world of education, many of the advantages that can be gained in the use of film as a medium for conveying the lessons toward students. As revealed by Usman (2002), advantage or benefit of film as a medium of teaching, among others (1) the film can illustrate a process, for example, the process of making the skills of hands and so on, (2) may give rise to an impression of space and time (3) his iconography are 3 dimensional, (4) the resulting sound can evoke reality in the image in the form of pure expression, (5) can convey the voice of an expert while seeing his performance, (6) If the film will be able to add colored reality object that is practiced, and (7) may describe the theories and science of animation. In the meantime, to get a good movie, it needs to design film that can meet the needs of students in relation to what is studied.

\subsection{Representation of Minangkabau Culture through Film}

Have been many movies produced with the Minangkabau cultural nuance, including Siti Nurbaya, Sengsara Membawa Nikmat, Merantau, Tenggelamnya Kapal Van Der Wijck and others. Don't just follow the story line, but in the movie there are also representations of Minangkabau culture, so the younger generation can learn and know the culture and customs of the Minangkabau through film. Based on the results of the research conducted Dewi Inrasari[13], about the Minangkabau culture reprsentasi in movies "Tenggelamnya Kapal Van Der Wijck" were analyzed using semiotics model Charles Sander Pierce, noted that:

1. The Minangkabau Culture symbolized in the film"Tenggelamnya Kapal Van Der Wijck" realized through the use of language, clothing, and customs, which is displayed through a few scenes, like a scenes featuring such traditional carriage transport commonly used by the people of Minangkabau in 1930 's, frequently deta used in everyday life as the embodiment of the Minangkabau community identity, pictures of mosques with a pointy roof shapes up, house building that extends with a pointy roof up called home or usual gadang in call home bagonjong, biological and Mamaknya which talks about the customs of the Minangkabau, deliberations conducted indigenous nobles Batipo that discusses the application of Azis and Zaenuddin, and scenes showing a series of biological and marriage the Azis using a custom Policy.

2. The meaning of the Minangkabau cultural symbol in the movie Tenggelamnya Kapal Van Der Wijck is a form of criticism of the culture of the Minangkabau matrilineal system of subsistence and materialistic. In the film, tells the story of a young man who suffered discrimination from the Minangkabau society treatment because of his social status and lineage and a woman whose life was ruined because of custom and culture. The Minangkabau society using custom reasons for material needs, so the film was used to criticize the social imbalances in society. This film reminded to establish rapport with someone regardless of material interests.

Then there's the film merantau is one means of preserving the culture of pencak silat, was deliberately created by the makers of film as a form of it against the preservation of the martial art pencak silat, especially pencak silat Minangkabau i.e. commonly known as silek Tiger/Tiger silat. Movies with themes of pencak silat is expected could spur community Indonesia to preserve one of the nation's culture, that of pencak silat Film Merantau raised Indonesia's cultural heritage that is the martial art pencak silat Minangkabau in particular the Tiger as the study of the film gives new nuances in Indonesia with a film showing scenes of martial arts fights the TigerAside from conserve pencak silat, the film also tells the story of a wandering culture is often done the majority of the citizens of the Minangkabau. In the tradition of the Minangkabau, where every boy will one day come out to wander outside of its territory. Aim so 
that the boys can find his real destination and then return home becomes a whole man to his hometown. In this movie is told about the journey of a teenager who wandered from his homeland on the ranah Minang to the capital with armed with the expertise of pencak silat Tiger.

Meanwhile film Siti Nurbaya adaptation of the novel Memang Jodoh the work of Marah rusli. Refer to the results of research Muqtafi dkk[14], in the film Siti Nurbaya described that the system of the Minangkabau community generally divides into several systems namely; the system of kinship, marriage system, and the legal system.

Society of Minangkabau matrilineal kinship system embraced. Matrilineal system was the system that regulates life and order a society bound to renew kinship in the maternal lineage.

1) System of marriage is the way certain community groups committed to create a bond born of inner between a man and woman as husband and wife. The system of the Minangkabau society embraced marriage set up that marriage is the responsibility of parents and Mamak (brother of mother). The child to be bred are required to follow the decisions of parents and mamak.

2) Minangkabau Culture knowledge systems relates to the concept of education, encourage the people to love of education and science. Since a small Minangkabau youths have been required to seek knowledge. The Minangkabau society view which says that"alam terkembang menjadi guru" It is a cornerstone of the Minangkabau society invited to always study. in the early days of Islam in Minangkabau society tengahtengah, the youth of the Minangkabau are required to learn the Customs and religious knowledge. It encourages every family to establish a surau as a place of study for the youth of the village. The spirit of the Minangkabau society in the study is not limited to home only.

3 in the early days of Islam in Minangkabau society, the youth of the Minangkabau are required to learn the Customs and religious studies. It encourages every family to establish a surau as a place of study for the youth of the village. The spirit of the Minangkabau society in the study is not limited to home only. Many of those who go abroad for the anticipated level of higher education, the purpose of their school into the Netherlands and Java.

4) aspects of religion (beliefs), in principle the Minangkabau society embraced Islam. Therefore, most of the Minangkabau adat community based on the teachings of Islam. In addition to believe the truth of the teachings of Islam, the Minangkabau communities living in rural areas still believe against things that are magical and superstitious. Siti Nurbaya which in the film departs from the novel Indeed Partner described that society of Minangkabau shaman and guna-guna.

To see the level of understanding of film as a means of learning and preservation of Minangkabau culture local wisdom then conducted a survey using the now on 30 people of the young generation in Minangkabau. Data collection now consists of seven questions as follows: (1) Did you ever watch the movie Siti Nurbaya/ Sengsara Membawa Nikmat/ Merantau/ Tenggelamnya Kapal van Derwijk? (Yuo can choise one), (2) Do you like the feel of the Minangkabau culture displayed by the film? (3) whether the film is easily understood (4) If you can figure out the nature of the character or character in the film? (5) What is the feeling you get carried away when watching the movie or after witnessing? (6) What is the benefit to you? (7) Did you learn the Minangkabau culture is more fun with the media movie or book?

The question form was distributed randomly to the younger generation in the Minangkabau who never watch the film with the heading local knowledge of the policy. It is expected that they can provide assessment of the films have been watched. Based on the results of a survey conducted on students that there are some results as follows: 
Table. 1 Film survey as local wisdom preservation media

\begin{tabular}{clc}
\hline No & \multicolumn{1}{c}{ Indicator } & Percent \\
\hline 1 & $\begin{array}{l}\text { Ever watch a movie with the Minangkabau local knowledge } \\
\text { content }\end{array}$ & 96,6 \\
2 & Interest in the background of the setting of the film & 80,0 \\
3 & The level of understanding of the background of the film & 86,6 \\
4 & The nature of the character figures & 83,3 \\
5 & Feelings come along get carried away with the story the & 70,0 \\
& movie & 93,0 \\
6 & The film is benefit for you. & 96,0 \\
& Learn the Minangkabau culture more enjoyable through the & \\
\hline
\end{tabular}

Based on the survey results data can be understood that the majority of respondents have an interest towards movies containing local knowledge of the policy, it is apparent from the percentage numbers $96,6 \%$ reponden ever watch the movie with background knowledge of the local Minangkabau. Furthermore, a number of 93,0\% declare film Minangkabau beneficial, and $96,6 \%$ stated more interested in Minangkabau culture with colleagues specializing use film. Thus it can be concluded the movie is an effective learning media in the transfer of local knowledge of the policy.

Based on the survey results as well as refer to results of research Husmiati [15] [16], it can be concluded that the use of film as a means of learning and the preservation of local wisdom has several advantages, including the following.

a. Make the learning of local wisdom Minangkabau more interesting and varied. A lot of media that are used in the process of learning such as transparencies, slides, audio tape, film, kompulis, games, television etc. But of the many media that can be applied, the media is one of the film's alternate learning process in the classroom that can reach a great class and thorough coverage. The film is a study of the media move with media audio system, making learning more interesting and varied as the medium of education for the knowledge transfer local wisdom Minangkabau.

b. Stimulate the imagination. The film can stimulate the imagination of learners. From the answers question form and concept of the exposure media excellence previously seen the film. By using the film medium can mengkonkritkan something before the abstract, the movie can also penetrate the space and time so this makes more markedly and attract the attention of students rather than just reading books on the Minangkabau culture, or hear the lecture and discussion. Through the film as a medium of learning kerifan local Minangkabau respondents indirectly can see period or time. Media film are able to bring the respondent indirectly from time to time, the other about the events contained in the film and was also able to bring the respondents from the setting/place to place the other indirectly. Media movies can make a lecture to be attractive and in price.

c. Critical understanding of historical events and culture. With the use of the film medium can stimulate the imagination, most respondents this will make the imagination and the way of thinking as more developed so that respondents can make students more critical understanding of historical events

d. Make it easier to explain the events, conditions and rules of customs. This relates to the use of the film medium can make and it is good to explain the provisions of the customs, norms and various forms of ceremonial culture 
e. Make the abstract becomes concrete. The survey results also showed that the condition of the respondent argues the media film as a medium of learning and the preservation of local wisdom the Minangkabau may explain the reality of the culture and customs of David's abstract can be dikongkritkan in time short

f. Quick recall and understand the terms of the Customs istiadan and culture . After seeing the film presented in the learning, media of film as a medium of learning local wisdom Minangkabau is able to make quick learners remember and understand the local wisdom of the policy.

g. The Film as a delightful audio visual. From a variety of media excess film as a medium of instruction, local wisdom Minangkabau turns the movie as audio visual media featuring the moving image and sound provide fun for students as the respondent.

h. Making learning effective and active. It turns out that in addition to the film media fun student, media movies also helps students learn actively and creating effective learning.

i. Improving the results of the The advantages of media film as a medium of learning history exciting, fun and besides create the motivation to learn can also improve students study history results in lectures.

\section{CONCLUSIONS}

The study concluded that use of film in preservation of indigenous knowledge there are several advantages: (a) the learning process so interesting, (b) stimulated of the imagination, (c) critical understanding of historical events and culture, (d) make it easier to explain the events, conditions and customs rules, (e) make the abstract becomes concrete, (f) quick recall and understand the terms of costoms and culture, $(\mathrm{g})$ the film as a delightful audio visual media, (h) making learning effective and active, and (i) improve learning result. Thus the movie can serve as an effective medium in the preservation of indigenous knowledge.

\section{REFERENCE}

[1] I. Kemal, Pemerintahan Nagari Minangkabau \& Pekermbanganya: Tinjauan Tentang Kerapatan Adat. Yogyakarta: Graha Ilmu, 2009.

[2] M. Fadli, W. Erwina, and N. Prahatmaja, "Preservasi Pengetahuan Masyarakat Minangkabau tentang Tradisi Pasambahan melalui Kegiatan Exchange of Indigenous Knowledge," Students e-Journal, 2012.

[3] N. Gorjestani, "Indigenous Knowledge For Development," Anthropol. News, vol. 40, no. 7, pp. 20-20, 1999.

[4] A. Hendriyana, "Indigenous Knowledge System for Health Communication and Information in Indonesia," Unpad, 2012. [Online]. Available: http://www.unpad.ac.id/en /2012/03/05/ indigenous-knowledge-important-foreffective-health-communication/ .

[5] B. Faust, "Implementation of Tacit Knowledge Preservation and Transfer Methods," Int. At. Energy Agency, 2010.

[6] A. Lalonde et al., "Indigenous Knowledge for Development: A Framework for Action," Transcience, 1998.

[7] D. Mulyana, Ilmu Komunikasi: Suatu Pengantar. Bandung: Remaja Rosda Karya, 2007.

[8] Sherri L. Jackson, Research Methods and Statistics: A Critical Approach. United State: Wadsworth Publishing, 2011.

[9] M. Easwaramoorthy, F. Zarinpoush, and Canada Volunteerism Initiative, Interviewing 
for Research. Canada: Imagine Canada, 2006.

[10] B. Kitchenham, "Procedures for performing systematic reviews," Keele Univ. Natl. ICT Aust., 2004.

[11] Nazir, Metode Penelitian. Jakarta: Rineka Cipta, 1998.

[12] M. A. Handayani, "Studi Peran Film dalam Dunia Pendidikan," Insa. J. Pemikir. Altern. Kependidikan, 1970.

[13] D. Inrasari, "Representasi Nilai Budaya Minangkabau Dalam Film "Tenggelamnya Kapal Van Der Wijck," Universitas Islam Negeri (Uin) Alauddin Makassar, 2015.

[14] A. S. Moh. Muqtafi, Sri Mariati, "Budaya Masyarakat Minangkabau Dalam Novel Memang Jodoh Karya Marah Rusli (Kajian Antropologi Sastra),” J. Publika Budaya, vol. 1, no. 1, pp. 7-11, 2015.

[15] R. Husmiati, "Kelebihan Dan Kelemahan Media Film Sebagai Media Pembelajaran Sejarah,” J. Sej. Lontar, 2017.

[16] K. Saddhono, "Integrating Culture in Indonesian Language Learning for Foreign Speakers at Indonesian Universities." J. of Lang. and Lit. vol. 6 no.2 pp. 349-353, 2015 